\title{
Trudności mtodego Kościoła w gtoszeniu Ewangelii w świetle Dziejów Apostolskich (Dz 8,5-24; 14,8-18). Refleksja biblijno-teologiczna
}

Głównym tematem podejmowanym przez autora Dziejów Apostolskich jest rozszerzanie się Słowa Zbawienia, zgodnie z wyznaczonym przez Chrystusa planem: ale gdy Duch Święty zstapi na was, otrzymacie Jego moc i będziecie moimi świadkami $w$ Jerozolimie $i w$ całej Judei, $i w$ Samarii, $i$ az po krańce ziemi $(\mathrm{Dz} 1,8)^{1}$. W tym planie rodzący się Kościół jawi się jako odpowiedni kontynuator Bożej drogi wyznaczonej mu przez Zbawiciela². Realizując powierzone mu zadanie ${ }^{3}$, Kościół musiał zmierzyć się z przeróżnymi przeciwnościami występującymi niemal we wszystkich sferach działalności i życia człowieka. W niniejszym artykule przyjrzymy się problemom związanym z politeistyczną mentalnością pogan oraz jej bezpośrednią konsekwencją w postaci błędnych koncepcji bóstwa w nich zakorzenionych, prowadzących z kolei do różnych form bałwochwalstwa. W tym miejscu należy zaznaczyć, iż z racji ograniczoności związanej z przyjętą formą artykułu konieczne było skupienie naszej uwagi jedynie na dwóch wybranych perykopach z Dziejów Apostolskich. Zarysowane przez nas powyżej problemy w sposób szczególny są widoczne na płaszczyznach: pogańskiej, głównie grecko-rzymskiej religijności, oraz w magicznym sposobie myślenia i mentalności. W związku z tym artykuł został podzielony na dwie

${ }^{1}$ R.J. Dillon, Dzieje Apostolskie, w: Katolicki komentarz biblijny (PSB), red. R.E. Brown - J.A. Fitzmyer - R.E. Murphy, Warszawa 2001, 1178-1179.

2 „Zbawienie rozpoczęło swoisty «podbój świata» od przyjścia na świat Jezusa Chrystusa i od zainicjowania przez Niego publicznej działalności w synagodze w Nazarecie (por. Łk 4,16-30), a swoje uwieńczenie znalazło w zaniesieniu go przez Apostołów i uczniów Jezusa aż po krańce ziemi, czyli do Rzymu, stolicy ówczesnego świata. Stąd nie dziwi, że pojęcie «zbawienia» wyrażone jest dosłownie na początku Ewangelii $(1,69.77 ; 3,6)$ oraz na końcu Dziejów Apostolskich $(28,28)$ ". P. Nyk, „Głosić słowo Boże z mocq” (Dz, 4,23-31), VV 7 (2005) 139.

${ }^{3}$ Całą historię chrześcijańską możemy w znacznej mierze określić mianem historii misji, zaś sam okres apostolski jest w całości jej poświęcony. Por. J. Gnilka, Pierwsi chrześcijanie. Źródła i poczqtki Kościoła, tł. W. Szymona, Kraków 2004, 341. 
części: 1. Ludzie czy Bogowie? Epizod Pawła i Barnaby w Listrze (Dz 14,8-18); 2. Konfrontacja z myślą i mentalnością magiczną (Dz 8,5-24).

\section{Ludzie czy Bogowie? Epizod Pawta i Barnaby w Listrze (Dz 14,8-18)}

Dz 14,8-18 pokrótce możemy nazwać relacją o uzdrowieniu mającym miejsce w Listrze ${ }^{4}$, po którym następuje bałwochwalcza reakcja ludu i konfrontacja apostołów z rozentuzjazmowanym tłumem. Wagę opisywanego przez Łukasza wydarzenia wzmaga dodatkowo fakt, iż po raz pierwszy na kartach Dziejów Apostolskich orędzie chrześcijańskie jest głoszone w ścisłym sensie poganom 5 .

Przyglądając się powyższej relacji, w sposób oczywisty narzuca się nam jej struktura koncentryczna składająca się z trzech tekstów ${ }^{6}$ : ww. 8-10 mówiące o nauczaniu Pawła Apostoła i dokonanym przez niego uzdrowieniu ${ }^{7}$ sparaliżowanego człowieka; ww. 11-13 opisujące reakcje tłumu na widok dokonanego uzdrowienia oraz chwilowy brak rozeznania w nowej sytuacji przez Pawła i Barnabę; ww. 14-18 zawierające relacje o zdecydowanym działaniu misjonarzy orientujących się w sytuacji i przeprowadzaniu przez nich ponownej nauki.

Najbardziej interesujące dla nas wydają się być wersety 11-13, w których to Paweł i Barnaba spotkali się ze skrajną postacią bałwochwalstwa, jaką jest

${ }^{4}$ Listra - miasto zachodniej Likaonii usytuowane na wzgórzu niedaleko Khatyn Serai, około 30-40 km na południowy zachód od Ikonium. Od 6 r. przed narodzeniem Chrystusa miasto było kolonią rzymską, z której August uczynił twierdzę mającą chronić okolicę przed plemionami zamieszkującymi górzyste obszary tego rejonu. Ludność zamieszkująca Likaonię posługiwała się własnym językiem. Mieszkańcy samej Listry w znaczącej większości składali się z ludności prostej i niewykształconej. Za murami obronnymi miasta znajdowała się świątynia poświęcona Zeusowi. Dokładne położenie miasta zlokalizował dopiero w 1885 r. John Robert Sitlington, który odnalazł ołtarz z inskrypcją zawierającą łacińską nazwę miasta. Por. Listra, w: Encyklopedia Katolicka (= EK), t. X, Lublin 2004; Listra, w: Encyklopedia Biblijna (PSB), Warszawa 1999.

${ }^{5}$ Por. W. Rakocy, „Będziecie moimi świadkami...” (Dz 1,8), w: Dzieje Apostolskie, Listy św. Pawła (WMWKB 9), red. J. Frankowski - S. Mędala, Warszawa 1997, 69.

${ }^{6}$ Przyjęty przez nas podział wydaje się być najwłaściwszy z punktu widzenia tematu i przyjętej formy naszej pracy. Należy również zaznaczyć, że tak jak w innych perykopach złożonych koncentrycznie, tak i w tej wersety centralne wydają się najważniejsze dla całego opowiadania.

${ }^{7}$ Relacja o uzdrowieniu (ww. 8-11) zawiera typowe elementy formalne tego gatunku znane z Ewangelii synoptycznych, tj.: wprowadzenie (ww. 8-9a); słowa i gesty uzdrowiciela (ww. 9b10a); uzdrowienie (w. 10b); wrażenie, jakie ów czyn wywarł na obserwatorach zdarzenia (ww. 11-13). Por. R.J. Dillon, Dzieje Apostolskie, 1197. 1222. 
uznanie istoty ludzkiej za boską, stworzenia - za Stwórcę. To zachowanie śmiało możemy uznać za formę idolatrii materialnej bezpośredniej, którego przyczyny, jak wskazuje uważna lektura Dz 14,8-18, należałoby szukać głęboko w wewnętrznej świadomości religijnej, w sercach i umysłach mieszkańców Listry, w których to przez wierzenia i mity zostały ukształtowane i zakorzenione błędne koncepcje bóstwa, a co za tym idzie - również skłonności do materialnego i duchowego bałwochwalstwa ${ }^{8}$. Utożsamienie Pawła i Barnaby kolejno z Hermesem i Zeusem (w. 12) wydaje się zatem konsekwencją niedojrzałości religijnej mieszkańców Listry, w większości prostych i niewykształconych ${ }^{9}$. W tym miejscu należy zauważyć, że - w odróżnieniu od ludności wywodzącej się z kręgu kultury żydowskiej, w której świadomości rzeczą oczywistą było, że to Bóg jest głównym sprawcą uzdrowien, których dokonuje za pośrednictwem swych ludzkich posłańców - w mentalności pogan, mających swe korzenie w kulturze grecko-rzymskiej, uzdrowienia przypisywano bogom objawiającym się w ludzkiej postaci ${ }^{10}$.

$\mathrm{Z}$ dokonanej przez nas dotychczasowej analizy wynikałoby, że dla tematu niniejszego przedłożenia najważniejsze są słowa zawarte w w. 11b, zawierające wyznanie i przeświadczenie mieszkańców Listry o boskim pochodzeniu Pawła i Barnaby, jednakże owa reakcja jest, jak powyżej napisaliśmy, formą idolatrii materialnej bezpośredniej, będącej tylko manifestacją obrazu bóstwa, jakie nosili tamtejsi mieszkańcy. Dlatego prawdopodobne wydaje się również przypuszczenie, iż większą wagę mają dla naszych badań wersety opisujące reakcje mężów Bożych (Dz 14,14-15nn), gdyż wyjaśniają przyczynę problemu, demaskując owe koncepcje bałwochwalcze i obrazy bóstwa drzemiące w sercach i umysłach ludności Listry. Tym samym pozwalają wyciągnąć, zarówno apostołom, jak i czytelnikom, wnioski zapobiegające powtórzeniu się podobnej sytuacji w przyszłości.

${ }^{8}$ Wyczerpujące studium na temat istoty bałwochwalstwa, występującego na kartach Biblii, i różnych form jego występowania - D. Kotecki, Co ma jeszcze chrześcijanin wspólnego z bożkami? Refleksja biblijno-teologiczna, w: Sentire cum Ecclesia, Fs. S. Grzechowiak, T. Makowski, red. P. Podeszwa, Gniezno 2004, 199-221.

${ }^{9}$ Por. Listra, w: EK.

${ }^{10}$ W. Rakocy podaje, że znaczna większość egzegetów, omawiając perykopę Dz 14,8-18, odwołuje się do przekazanej przez Owidiusza legendy o Zeusie i Hermesie, którzy przebrani za ludzi mieli odwiedzić pobliski region Frygii. Jednakże, jak dalej podaje autor, nie posiadamy żadnych przekonujących świadectw, że owa legenda była znana mieszkańcom Listry. Co prawda prof. W.M. Calder w 1910 r. odnalazł dwie inskrypcje wspominające obydwa bóstwa, z racji jednak, iż pochodzą one z III w. po Chrystusie, a dodatkowo zostały sporządzone w języku greckim, a nie likońskim, nie mają one wielkiej siły dowodowej. Por. W. Rakocy, „Będziecie moimi świadkami...” (Dz, 1,8), 69-70. 
Podążając dalej powyższym tokiem myślenia, wydaje się usprawiedliwione wysunięcie teorii mówiącej, że Paweł i Barnaba (w. 14) zdali sobie sprawę, iż w wyniku niewystarczającego przygotowania ludu (w. 9a) w stosunku do dokonanego przez siebie znaku, jakim było uzdrowienie (w. 10), nieświadomie zaciągnęli winę przez przysłonięcie osoby Boga. Wynikiem tego było odciągnięcie ludu od Boga i uznanie samych apostołów za Zeusa i Hermesa. W tym świetle rozerwanie szat przez Pawła i Barnabę może nie tylko oznaczać wyraz dezaprobaty i oburzenia, ale również uznanie swej winy względem Bogiem i przed nim, a tym samym - wyznanie gotowości do naprawienia wywołanego przez siebie stanu rzeczy ${ }^{11}$. Na potwierdzenie powyższej tezy wydaje się przemawiać w. 15, w którym misjonarze „desperacko” dokonują powtórnej nauki, której wynikiem jest jedynie powstrzymanie ludu od złożenia im ofiar.

W tak nakreślonej optyce lektura Dz 14,8-18 uświadamia, jak wielki ciężar i odpowiedzialność spoczywa na barkach ludzi głoszących Słowo Boże. Jak zauważyliśmy powyżej, „wyznanie wiary” (w. 11b) mieszkańców Listry było spowodowane nieodpowiednim doborem środka ewangelizacji w stosunku do grupy poddawanej naukom. Sam uzdrowiony, co wyraźnie zaznacza św. Łukasz, był przygotowany na dokonany na nim cud: Stuchat on przemówienia Pawła; ten spojrzał na niego uważnie $i$ widzqc, że ma wiare potrzebnq do uzdrowienia, zawołał głośno: Stań prosto na nogach! A on zerwat się i zaczq̨t chodzić (Dz 14,9-10), jednakże autor nic nie wspomina na temat gotowości tłumu. Pozwala to nam wywnioskować, że najprawdopodobniej św. Paweł nie dokonał analizy stopnia przygotowania tłumu naznak, który uczynił. Dlategoteż, po uświadomieniu sobie skutków swojego błędnego działania, Paweł wraz z Barnabą rozrywają swoje szaty, co, jak wyżej zinterpretowaliśmy, było aktem wskazującym na zrozumienie ciężaru popełnionego czynu. Na usprawiedliwienie Pawła przemawia fakt, iż nigdy dotąd po dokonaniu czynu uzdrowienia nie doprowadzał on jego świadków do idolatrii, a wręcz przeciwnie - był on niezawodnym narzędziem doprowadzającym do prawdziwej wiary jego bezpośrednich obserwatorów (por. Dz 3,1-10; 9,32-35). Paweł i Barnaba po prostu nie wzięli pod uwagę tego, że przyszło im działać w środowisku innym pod względem mentalności religijnospołecznej ${ }^{12}$, niż dotychczasowo spotkane.

Reasumując, wydarzenia opisywane w Dz 14,8-18 pouczają, że ewangelizując wśród nowej grupy osób (zwłaszcza, gdy jest ona inna niż dotychczasowo

${ }^{11}$ Poprzez daleko idącą analogię możemy porównać reakcje Pawła i Barnaby do reakcji króla Dawida, kiedy to po interwencji proroka Natana uświadomił sobie ogrom swojej winy (2 Sm 12,114). Zasadnicza różnica w tym spojrzeniu polega na tym, iż ewangelizatorzy, jako głosicie Słowa, „posiadali” Ducha Świętego, zaś Dawid potrzebował do nawrócenia i pokuty osoby proroka.

${ }^{12}$ Por. W. Rakocy, „Będziecie moimi świadkami...” (Dz 1,8), 69. 
spotkane), należy zawsze bezwzględnie dokonać rozeznania realiów środowiska, w jakim głoszone jest Słowo Boże. Równie ważną sprawą jest stopniowe nauczanie i przygotowywanie osób katechizowanych i ewangelizowanych do trudniejszych prawd wiary, co zakłada oparcie się wewnętrznej pokusie szybkiego otrzymania upragnionych efektów. Istotne wydaje się także współmierne i przemyślane dobieranie środków oraz metod ewangelicznych. Oczywiście w dzisiejszych realiach kulturowych wystąpienie omawianego przez nas problemu idolatrii w tak skrajnej postaci jest wielce nieprawdopodobne, a nawet niemożliwe, jednak nadal realne jest niebezpieczeństwo, że poprzez nieprzemyślane działanie duszpasterza może on przysłonić osobę Jezusa Chrystusa.

\section{Konfrontacja z myślạ i mentalnością magicznạ (Dz 8,5-24)}

Na kartach Nowego Testamentu problem magii dochodzi do głosu wraz z faktem rozpoczęcia głoszenia Dobrej Nowiny poza granicami Judei i narodu wybranego oraz sferą wpływów ortodoksyjnego judaizmu. Warto zauważyć, iż zarówno w Ewangeliach synoptycznych, jak i Ewangelii św. Jana Jezus nie odnosi się wprost do tematu magii, tak jakby ten problem nie dotyczył Galilei i Judei, gdzie nauczał. Jedynie w „Ewangelii dzieciństwa” św. Mateusza został poruszony temat astrologii. Problem magii został również podjęty w Apokalipsie, jednakże najbardziej plastyczne i dramatyczne ujęcie powyższego zagadnienia prezentują Dzieje Apostolskie, gdzie w kontekście ewangelizacji dochodzi do obłożenia klątwą przez głosicieli Ewangelii osób parających się magią (por Dz 8,20-23; 13,10-11), co stanowi kontynuację tradycji starotestamentalnej. W Dziejach Apostolskich spotykamy cztery opisy miejsc i sytuacji, w których dochodzi do konfrontacji ewangelizatorów z przedstawicielami świata i myślenia magicznego (Dz 8,5-24; 13,4-12; 16,16-21; 19,11-20) ${ }^{13}$.

W tej części artykułu, jak zaznaczyliśmy we wstępie, przyjrzymy się lekcji zawartej w Dz 8,5-24, której przesłanie wydaje się najbardziej właściwe dla przybliżenia i zrozumienia interesującej nas tematyki. Pominięcie wyżej wymienionych tekstów, zawierających opisy spotkania się ewangelizatorów ze światem magii i jej przedstawicielami, podyktowane jest, jak już wspominaliśmy, ograniczonością przyjętej przez nas formy, jaką jest artykuł. Zanim przejdziemy do analizy wybranych perykop, należy jeszcze poruszyć dwie zasadnicze kwestie, a mianowicie: co Biblia rozumie pod pojęciem magii?, oraz: jaką jej nadaje ocenę?

${ }^{13}$ R. Pindel, Magia czy Ewangelia? Konfrontacja głosicieli Ewangelii ze światem magicznym w ujęciu Dziejów Apostolskich, Kraków 2003, 80. 86. 279. 
Działanie magiczne, jak to ukazuje Pismo Święte, jest aktem mającym na celu uzurpację przez człowieka władzy i wiedzy nieprzynależnej mu z natury. Sama czynność magiczna polega na odwołaniu się do nadnaturalnych mocy w celu zmiany rzeczywistości według woli i oczekiwań osoby podejmującej owo działanie w sposób przeciwny naturze. Charakterystyczne dla aktów magicznych jest stosowanie przymusu wobec istot, sił nadnaturalnych, do których się odwołuje. Ów przymus mają zapewnić osobie podejmującej czynności magiczne w jej przekonaniu: ryty, obrzędy, formuły słowne i przedmioty. Właściwa dla magii jest również wiara, iż wspomniane ryty i obrzędy, aby mieć moc i przynieść oczekiwany skutek, muszą być drobiazgowo i pieczołowicie wykonane odpowiednią ilość razy, w przeciwnym wypadku okażą się bezskuteczne, a nawet niebezpieczne dla osoby je stosującej. Akt magiczny może podejmować sama zainteresowana osoba lub, jeżeli brak jej kompetencji, profesjonalista w jej imieniu, jak to miało miejsce w przypadku króla Saula (1 Sm 25,3-25). Biblia wyróżnia, ze względu na sposób działania i oczekiwanego celu, następujące typy magii: nekromancja i różne sposoby wróżenia, astrologia, sposoby wyjaśniania snów oraz znaki „cudowne” i magia obronna ${ }^{14}$.

W tym miejscu należy zaznaczyć, iż wszelkie podziały wyprowadzane ze względu na zamierzony skutek działania magicznego ${ }^{15}$ są niewłaściwe, gdyż pozwalają przypuszczać, że w określonych przypadkach działanie magiczne możemy uznać za religijnie i moralnie dobre, zaś uzurpowanie przez człowieka wiedzy i władzy nieprzynależnej mu z natury, choć całkowicie złudnej, jak w przypadku magii (Mdr 17,7; Iz 47,9.12-13; Dz 13,4-12; 19,11-20; Ap 18,23), jest zawsze ciężkim wykroczeniem. Wagi takiego wykroczenia nie łagodzą intencje ani cele osoby, która je popełniła, z tej racji, iż cel nigdy nie może usprawiedliwić zastosowanych środków. Brak zaś w tekście oryginalnym dookreślenia, że Szymon zajmował się „czarną” magią, zdaje się jedynie potwierdzać, że magia jest jednoznacznie pejoratywnie oceniana przez Pismo Święte (Dz 8,9, por. również Pwt 18,10-11; Ap 9,20-21; 18,23; 21,8; 22,15; Ga 5,20-21; Kpł 19,19.26-31; 20,2-7.27; Iz 47,9.12-13; Mdr 17,7; 12,3-5; Ml 3,5).

${ }^{14}$ K.H. Peschke, Grzechy przeciwko kultowi prawdziwego Boga, Communio 15 (1995) 45. 57; R. Pindel, Magia czy Ewangelia?, 8. 11. 15-17. 339-340.

15 Przykładem tak przyjętego podziału, mogącego w czytelniku spowodować błędne przekonanie, jakoby pewne praktyki magiczne były moralnie dobre, są np. słowa K.H. Peschke (Grzechy przeciwko kultowi prawdziwego Boga, 57): „magia dzieli się na magię białą, która ma na celu skutki zdrowotne lub przynajmniej dozwolone, oraz na magię czarną, która usiłuje wywołać złe skutki lub zmierza do innych grzesznych celów". Oczywiście celem autora nie było wywołanie błędnego przekonania w odbiorcy, jednakże kontekst wypowiedzi nie dość wystarczająco wyklucza tego typu błędne rozumienie, pozwalając na nadinterpretacje przytoczonych słów. 
Analizując wybraną przez nas perykopę Dziejów Apostolskich (8,5-24), pominiemy zagadnienia dotyczące redakcji i historii tekstu z powodów zaznaczonych we wstępie, skupiając się na tekście kanonicznym w jego dzisiejszej formie. W lekcji Dz 8,5-24 zauważamy cztery segmenty tekstu: ww. 5-8 opisujące relacje z działalności ewangelizacyjnej Filipa w Samarii; ww. 9-13 przedstawiające pokrótce sylwetkę oraz wcześniejsze życie Szymona Maga i zawierające opis jego nawrócenia i przyjęcia chrztu; ww. 14-17 stanowiące opis misji i działalności Piotra i Jana w Samarii oraz ww. 18-24, w których dochodzi do konfrontacji Piotra z Szymonem i osądzenia sposobu myślenia i mentalności właściwej magii ${ }^{16}$.

Przyglądając się powyżej przedstawionej strukturze perykopy, właściwe wydaje się przyjęcie, że w rozważanej lekcji mamy do czynienia ze wzajemnym odpowiadaniem sobie poszczególnych bloków tekstów: segment $a$ (ww. 5-8) odpowiadający blokowi $a^{\prime}$ (ww. 9-13) oraz segment $b$ (ww. 14-17) korespondujący z jednostką $b^{\prime}$ (ww. 18-24). Dalszą analizę Dz 8,5-24 przeprowadzimy, opierając się o podział tekstu ze względu na paralelne bloki.

Pierwszą ważną informacją płynącą z lektury Dz 8,5-8.14-17, o której należy w tym miejscu wspomnieć, jest fakt zwrócenia się do Samarytan, który można rozumieć jako poważną próbę przezwyciężenia dziedzicznej nienawiści rodowej. Również istotne przesłanie stanowi łączność pomiędzy nowo założonym Kościołem w Samarii a Kościołem „Matką” w Jerozolimie, które staje się widoczne poprzez dopełnienie misji Filipa polegającej na udzielaniu chrztu, przez misje Apostołów Piotra i Jana, którzy poprzez modlitwę i nałożenie rąk udzielali Ducha Świętego. Zatem za sprawą przybycia i działalności Piotra i Jana misja Filipa została zaakceptowana, a Kościół w Samarii otrzymał gwarancje jedności z misją Chrystusa. Z historycznego punktu widzenia nieporównywalnie ważniejszym był jednak wspomniany postulat zaakceptowania Samarytan ${ }^{17}$.

Od strony tematyki poruszanej w naszej pracy większe znaczenie ma przesłanie płynące z egzegezy Dz 8,9-13.18-24. Wymienione fragmenty zawierają przedstawienie postaci Szymona ${ }^{18}$ zwanego Magiem oraz jego reakcji, wpierw na działalność ewangelizatorską i cudotwórczą Filipa - jednego z siedmiu (Dz 6,5), następnie na misje Apostołów Piotra i Jana. W wersetach 9-13 św. Łukasz

${ }^{16}$ Por. R. Pindel, Magia czy Ewangelia?, 281.

${ }^{17}$ Por. J. Gnilka, Piotr i Rzym. Obraz Piotra w pierwszych dwu wiekach, tł. W. Szymona, Kraków 2002, 104. Por. również H. Langkammer, Teologia Nowego Testamentu, cz. 1: Ewangelie - Dzieje Apostolskie - Listy Katolickie - Apokalipsa. Jezus Chrystus wczoraj - dziś - na wieki, Wrocław 1985, 218. 220; R.J. Dillon, Dzieje Apostolskie, 1210.

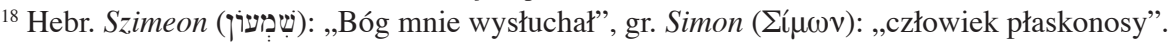
Por. P.Cz. Bosak, Szymon Mag, w: Postacie Nowego Testamentu. Słownik Konkordancja, Pelplin 1996. 
z jednej strony podkreśla podziw Samarytan dla umiejętności Szymona, z drugiej zaś od początku ukazuje, że mag znajduje się na przegranej pozycji w zestawieniu $\mathrm{z}$ orędziem Ewangelii, ponieważ ów podziwiany i poważany przez wszystkich znawca „sztuki magicznej” musiał uznać wyższość znaków i mocy Filipa. W tym kontekście godnym podkreślenia jest fakt, że Szymon podziw Samarytan musiał zdobywać przez długi czas, zaś Filip nie dość, iż zyskuje większe uznanie ze strony tłumów w nieporównywalnie krótszym czasie, to jeszcze sam mag, człowiek podziwiany, zostaje zafascynowany dziełami Diakona. Ów podziw ze strony Szymona wobec znaków dokonywanych przez Filipa dowodzi zatem, że magia i możliwości przez nią dawane są niczym w porównaniu do mocy, jaką Chrystus udziela głosicielom Ewangelii. Działalność Filipa w konsekwencji doprowadziła do aktu autentycznej, choć spowodowanej fascynacją, wiary ze strony Szymona i przyjęcia przez niego sakramentu chrztu. Jednakże wiara maga, która była wystarczająca do przyjęcia chrztu, nie przechodzi próby dojrzałości w zetknięciu z tajemnicą udzielania Ducha Świętego ${ }^{19}$.

Naganna postawa Szymona, wyrażająca się przez posiadanie swojej koncepcji na rolę Boga w jego życiu i na swoje bycie chrześcijaninem, zostaje zdemaskowana w związku z modlitwą Piotra i Jana nad ochrzczonymi, by ci otrzymali Ducha Świętego ${ }^{20}$. Przyczyny postawy Szymona, charakteryzującej się w posiadaniu własnego obrazu bóstwa, a wyrażającej się w chęci manipulowania Duchem Świętym dla własnej korzyści, należy dopatrywać się w wersetach 9-11. Zawierają one informacje na temat celów, dla których Szymon podejmował działania magiczne. Szymon na pierwszym miejscu proklamował tylko siebie i swoją wielkość. Wszelkie zaś dokonywane przez niego znaki, którymi zadziwiał, miały wskazywać na jego boskość i doprowadzić do podziwu dla jego osoby ${ }^{21}$. Tę skłonność do uwielbienia siebie Szymon wniósł, wraz z chrztem, na teren przyjętej przez siebie wiary. Chęć posiadania mocy Ducha Świętego dla dokonywania zdumiewających czynów nowej jakości w celu zyskania jeszcze większej sławy, sprawiła zamknięcie się Szymona na Boga i istotę kultu, jaką człowiek jest mu winien ${ }^{22}$.

${ }^{19}$ Por. R. Pindel, Magia czy Ewangelia?, 284-286.

${ }^{20}$ Religijność Szymona maga, będąc wciąż zbytnio osadzoną w rytach właściwych myśleniu magicznemu, miała dużo z tejże magii i zewnętrzności, a niewiele lub nic z wewnętrznej i osobowej więzi z Bogiem. Podobną sytuację niezrozumienia istoty prawdziwego kultu mamy w oskarżeniu o bałwochwalstwo skierowanym przez proroka Ozeasza do Izraela. Por. J. Warzecha, Niech każdy odrzuci bożki Ez 20,7, Communio 15 (1995) 8.

${ }^{21}$ Por. R. Pindel, Magia czy Ewangelia?, 285.

22 „W wyznawaniu wiary i w kulcie Bożym człowiek potwierdza podwójną rzeczywistość: po pierwsze, godzi się z tym, że sam nic nie znaczy, uznaje własną nicość i grzeszność wobec absolutnej pełni bytu i absolutnej świętości, to zaś rodzi szacunek, który powoduje dystans 
Próbując „kupić” Ducha Świętego w celu posiadania nad Nim władzy (Dz 8,19), Szymon zdradza swe niezrozumienie czynów, których jest świadkiem. Gest nałożenia rąk odczytuje on w kategoriach sztuki magicznej, w myśl której rytuał zapewniał władzę nad przyzywanym bóstwem. Mag wykazał zatem, że nadal, mimo przyjętego chrztu, tkwi w logice właściwej myśleniu magicznemu, tym samym nie zdał on próby dojrzałości wiary chrześcijańskiej i okazał się niezdolny do przyjęcia sakramentu bierzmowania. Próba Szymona potwierdziła zaś nienaruszalny charakter Ducha jako daru (Dz 8,20, por. również Dz 2,38; $10,45 ; 11,17)^{23}$.

Odrzucenie przez Piotra egoistycznych roszczeń Szymona Maga i skarcenie nieczystego posługiwania się pieniędzmi jest z jednej strony potwierdzeniem, iż dar Ducha nie może być zredukowany do rzeczy pozostającej w dyspozycji wolnej woli człowieka, modlitwa zaś o jego udzielenie nie może być rozumiana w kategoriach rytuałów magicznych. Z drugiej strony Apostoł, po linii starotestamentalnego rozróżniania prawdziwych i fałszywych proroków przez ich stosunek do pieniędzy, podał kryterium weryfikacji autentycznych głosicieli Ewangeliii ${ }^{24}$.

Z dotychczasowych analiz wynika zatem, że Szymon winien jest grzechu bałwochwalstwa przejawiającego się w dwóch aspektach: po pierwsze, pragnie on zastąpić Boga wartością dla niego najważniejszą, tj. samym sobą (idolatria materialna pośrednia); po drugie, manipuluje on obrazem Ducha Świętego poprzez ograniczenie jego władzy i woli (chęć „kupna”) za sprawą związania mu rąk przy pomocy rytuałów (idolatria duchowa), w tym przypadku źle rozumianego przez Szymona gestu nakładania rąk $^{25}$. W tym kontekście słowa Piotra skierowane do Maga nabierają szczególnie ważnej wymowy: Niech pieniqdze twoje przepadnq razem z tobq - odpowiedział mu Piotr - gdyż sqadziłeś, że dar Boży można nabyć za pieniqdze. Nie masz żadnego udziału w tym dziele, bo serce twoje nie jest prawe wobec Boga. Odwróć się więc od swego grzechu i proś Pana, a może ci odpuści twój zamiar. Bo widzę, że jesteś żótciq gorzkq i wiqzzkq

(mysterium tremendum); po drugie, uznaje on swą zależność od Stwórcy i swe istotowe ukierunkowanie na niosącą błogosławieństwo pełnię Boga, która i tylko ona jest w stanie przyjść z pomocą ludzkiej nędzy. Emanująca z Boga moc przyciągania domaga się gorącego pragnienia i pobożności pełnej miłości, to wszystko zaś rodzi jedność między Bogiem a człowiekiem (mysterium fascinosum). Cała religijność oscyluje miedzy dystansem, wynikającym z szacunku, a pełną miłości pobożnością, co jej nadaje moc i siłę”. K.H. Peschke, Grzechy przeciwko kultowi prawdziwego Boga, 43.

${ }^{23}$ Por. R.J. Dillon, Dzieje Apostolskie, 1210; R. Pindel, Magia czy Ewangelia?, 286-288.

${ }^{24}$ Por. J. Gnilka, Piotr i Rzym, 194-195; R. Pindel, Magia czy Ewangelia?, 289.

${ }^{25}$ Por. charakterystykę idolatrii materialnej pośredniej i duchowej w: D. Kotecki, Co ma jeszcze chrześcijanin wspólnego z bożkami?, 207-217. 
nieprawości (Dz 8,20-23). Apostoł wyraźnie przyczyny grzechu Szymona dopatruje się w kondycji jego serca spętanego więzami magii. Tym samym św. Łukasz wypowiada surową przestrogę pod adresem każdego chrześcijanina, a mianowicie: serce musi być szczere wobec Boga, bo inaczej może samo siebie zatracić (por. również: Ps 16,4; Ml 3,5; Ga 5,20-21). Autor ustami św. Piotra wzywa do przemiany myślenia wszystkich idących drogą Szymona - jest to wezwanie do zachowywania zawsze serca prawego wobec $\mathrm{Boga}^{26}$. Zatem serce chrześcijanina musi być zawsze otwarte na dary płynące od Boga, tj.: mądrość, wiedzę, wiarę; ma nie być „lepiej wiedzącym” i nie oczekiwać żadnych korzyści. „Serce jest [bowiem] miejscem decydującym o czystości człowieka i od serca zależy, czy człowiek należy do sfery Bożej i podoba się Bogu [...] Nieczystość serca oznacza wykluczenie Boga i zastąpienie Go innymi wartościami, które jawią się ważniejsze niż Bóg. Takie zastąpienie jest niczym innym jak bałwochwalstwem"27.

Zatem Nowy Testament zwraca szczególną uwagę na wnętrze człowieka, z którego to biorą swój początek wszelkie odstępstwa i bałwochwalstwo. Dlatego też Jezus wzywał do zachowania postawy pokory i uznania swojej całkowitej zależności od Boga we wszystkich wymiarach swojego życia: „Błogosławieni ubodzy w duchu, albowiem do nich należy królestwo niebieskie" (Mt 5,3) oraz do zachowania czystości relacji względem Boga: „Błogosławieni czystego serca, albowiem oni Boga oglądać będą" (Mt 5,8). Również wezwania Jezusa: „Czas się wypełnił i bliskie jest królestwo Boże. Nawracajcie się i wierzcie w Ewangelię" (Mk 1,15) nie należy odczytywać jako wezwania do manipulowania Bogiem, ale do uznania Go takim, jakim rzeczywiście jest ${ }^{28}$.

Z naszych dotychczasowych analiz wynika, że perykopa Dz 8,5-24 powinna być rozumiana jako swojego rodzaju ponadczasowe ostrzeżenie skierowane do samego czytelnika, aby krocząc drogą wiary chrześcijańskiej, nieustannie weryfikować kondycję swojego serca, nieustannie starać się zachować je prawym względem Boga poprzez łączność z Kościołem, a przede wszystkim poprzez żywe życie sakramentalne. Przypadek Szymona Maga uczy również, że przyjęcie chrztu nie gwarantuje właściwej postawy duchowo-religijnej chrześcijan względem Boga. Dlatego też należy nieustannie obdarzać troską wiernych poprzez praktykę duszpasterską, nauczanie i prowadzenie do poznania i zawiązania żywej komunii oraz właściwych relacji z Bogiem.

\footnotetext{
${ }^{26}$ Por. R. Pindel, Magia czy Ewangelia?, 290-292.

${ }^{27}$ D. Kotecki, Co ma jeszcze chrześcijanin wspólnego z bożkami?, 213.

${ }^{28}$ Por. tamże, 212-113. 216-217.
} 


\section{Zakończenie}

Zagadnienia bałwochwalstwa i magii nie są pierwszorzędnymi ani dominującymi w Dziejach Apostolskich, ale należą do elementów składowych tematu ewangelizacji (por. Dz 1,8). W tym właśnie kontekście powinny być odczytywane. Nauki płynące $\mathrm{z}$ analizowanych przez nas perykop w temacie, jakim jest rozszerzanie się Słowa Bożego, nabierają ponadczasowej wagi. Dziś szczególnie w kontekście synkretyzmu proponowanego przez New Age są one aktualne. Przesłanie Dziejów Apostolskich 8,5-24 i 14,8-18 wzywa wszystkich, którym została powierzona piecza nad depozytem wiary, aby głosili jasne orędzie Ewangelii w sposób autorytatywny i zrozumiały dla odbiorcy. Należy bowiem pamiętać, że różne prądy światopoglądowe i „religijne” nieustannie próbują odwieść każdego, kogo się da, od bliskości Boga. Czynią to poprzez zatruwanie ludzkich serc bałwochwalczymi koncepcjami zarówno Osoby Boga, jak i spekulacjami na temat miejsca i roli człowieka we wszechświecie. W tym miejscu wyrażamy nadzieję, że poprzez przedstawioną w niniejszym artykule problematykę ukazane zostały narzędzia ostrzegające wszystkich przed zagrożeniami płynącymi ze strony świata. 


\section{Zusammenfassung}

Der Artikel zeigt in zwei Teilen die besondere Wirkung des Heiligen Geistes. Im ersten Abschnitt (Apg 8,5-24) die Geistesmitteilung durch die Apostel macht auf Simon gewaltigen Eindruck, offenbart aber zugleich das wahre Motiv für sein Gläubigwerden. Er hat sich von Philippus nur taufen lassen, weil er in ihm einen machtvollen Wundertäter sah, aber das eigentliche Wesen der christlichen Religion ist ihm fremd geblieben. Und so sieht er auch in den Aposteln nur ihm überlegene Wundertäter und will derer höhere Kräfte, die er sich als Zauberkräfte denkt, um Geld für sich gewinnen. Die Macht der Apostel ist aber keine käufliche Zauberkraft, sondern eine freie Gabe Gottes, die man nicht mit Geld erwerben kann. Im zweiten Abschnitt (Apg 14,8-18) der Glaube der Bewohner von Lystra, dass Paulus und Barnabas Götter in Menschengestalt sind, ist so fest, dass die Priester des vor der Stadt befindlichen Zeustempels sich anschicken, den beiden vermeintlichen Götter zu opfern. Die Worte, die Apostel an die Menge richten, sind deshalb besonders wichtig, weil sie erkennen lassen, wie Paulus zu heidnischen Zuhörern gesprochen hat. Ihnen musste er zuerst die große Wahrheit von dem einen wahren Gott, dem Schöpfer und liebevollen Vater aller Menschen, verkünden. Und auf diese Wahrheit weisen die beiden Apostel auch bei dieser Gelegenheit mit Nachdruck hin. 